\title{
Pentecostalism and premarital sexual initiation in Brazil ${ }^{*}$
}

\author{
Ana Paula A. Verona* \\ Mark Regnerus ${ }^{* * *}$
}

\begin{abstract}
Pentecostal denominations in Brazil are recognized for their promotion of conservative norms and punitive sanctions related to the sexual behavior of their young members. Moreover, they have created unique space for their followers to actively participate in a religious environment. Using data from the PNDS-2006 (National Survey on the Demography and Health of Children and Women, Pesquisa Nacional de Demografia e Saúde da Criança e da Mulher de 2006), we examine the associations, in Brazil between religion, as measured by religious affiliation and attendance at religious services, and premarital adolescent sexual initiation. Our main results confirm a strong association between delay in sexual initiation and Pentecostalism in Brazil and suggest that this association be related to frequent attendance at religious services. These findings are intriguing, especially because Pentecostalism has emerged and concentrated among socioeconomically disadvantaged populations, including the least-educated women, with lower income, and residents of urban areas. We conclude by suggesting that religion may be taking the place of family and school in communication on adolescent sexual behavior in Brazil. This hypothesis should be carefully investigated, since the religious teachings may sometimes be in favor of what families and the state see as beneficial for adolescents and youth in general, but sometimes in disaccord.
\end{abstract}

Keywords: Religion. Religiosity. Premarital sexual initiation. Adolescent sexuality.

\footnotetext{
* A preliminary version of this article was presented at the 2009 meeting of the Population Association of America (PAA) in Detroit, Michigan. The authors would like to thank Fapemig (Edital 15/2010) and CNPq (Edital 07/2011) for financially supporting this research project.

${ }^{* *}$ Department of Demography/Centro de Desenvolvimento e Planejamento Regional - Cedeplar, Universidade Federal de Minas Gerais - UFMG, Belo Horizonte, Minas Gerais-MG, Brasil (anapaulaverona@gmail.com).

${ }_{* \star *}$ Department of Sociology, University of Texas at Austin, Austin, Texas, Estados Unidos (regnerus@prc.utexas.edu).
} 


\section{Introduction}

The percentage of adolescent women in Brazil who report never having had sexual intercourse fell dramatically in 20 years: from 80\% in 1986 (BEMFAM, 1986) to 45\% in 2006 (BRASIL, 2006). It is well documented that early sexual activity can lead to negative reproductive health outcomes for young women and other adolescents. In many countries, concern regarding unprotected sexual behavior, for instance, is evident both because of the increase in unintended premarital and pregnancies, unwanted childbearing and unsafe abortions, and due to the high risks of acquiring HIV and other sexually transmitted diseases (HEILBORN; AQUINO; KNAUTH, 2006; HINDIN; FATUSI, 2009; BANKOLE; MALARCHER, 2010). Other problematic consequences of early sexual initiation can be related to school dropout and lack of social support from families and partners (BONGAARTS; COHEN, 1998).

Declining age at first sexual intercourse has been accompanied by a transformation in Brazil's religious landscape. One of the changes associated with this phenomenon was the significant growth of evangelical Protestantism, led by Pentecostalism. With this growth, conservative norms regarding the sexual and reproductive behavior of adolescents and unmarried youth began to play an important and systematic role in the lives of these groups' young members (MARIANO, 2005; BURDICK, 1993). The Pentecostal movement, for instance, has promoted the dissemination of clear standards and objectives, along with punitive sanctions, especially in regard to the habits, family, and sexuality of its young adherents (MARIZ, 1994; PIERUCCI; PRANDI, 2000).

Moreover, Pentecostal churches have used different resources to create space to encourage young followers to actively participate in a religious environment. Youth groups, dating groups, counseling services, lectures on daily issues and other activities have frequently been observed in these churches in Brazil, which may have been successful at creating mechanisms through which religion can influence the lives and behavior of adolescents and young people.

The question we address in this paper is, what association may exist between Pentecostalism and age at first sexual intercourse in Brazil. We hypothesize that women in Brazil who currently belong to Pentecostal churches are at a lower risk of experiencing early sexual intercourse than those affiliated with the Roman Catholic Church. Because of the close connection between marriage and sexual activity, this analysis estimates the risk of the first sexual intercourse being premarital.

In addition, we hypothesize that girls with greater religious commitment (measured here as attendance at religious services) may be more apt to put their religious values and teachings into practice (REGNERUS, 2007). Likewise, they may be more exposed to the indirect effects of religion, as suggested by Smith (2003) and Verona (2011). It is certainly important to include both dimensions of religion (religious denomination and attendance at religious services) because this may help differentiate adolescents who belong to the same religion. This is particularly important when working with data on Catholics, the largest and perhaps most heterogeneous religious group in Brazil. 
A few studies have investigated the association between religion and adolescent sexual and reproductive behavior in Brazil. One such study was conducted by McKinnon, Potter and Garrard-Burnett (2008). Using the 2000 Brazilian census, this article explored the relationships between Protestantism, fertility and family formation among adolescents aged 15 to 17 living in the metropolitan region of Rio de Janeiro. Religion deserves further consideration when one analyzes such a topic, not only because Brazil has undergone enormous changes in its religious landscape, but also because religion is both a primary socialization agent of adolescents and because sexual activity is a sphere of human behavior considered high in religious applicability (REGNERUS, 2007).

The present study uses data from the PNDS-2006 (National Survey on the Demography and Health of Children and Women) (Pesquisa Nacional de Demografia e Saúde da Criança e da Mulher), a nationally representative survey of women between ages 15 and 49. The PNDS2006 provides information on age at first sexual intercourse, age at first union and attendance at religious services, all of which factors may contribute substantially to better understanding of the association between religion and adolescent premarital sexual initiation in Brazil.

\section{The influence of social groups and institutions on people's behavior}

Several analysts have argued that social institutions, primarily the family and religion, are sources of social control that govern sexual expression and behavior (DeLAMATER, 1981). This perspective postulates that people are naturally inclined toward deviance that can be restrained by bonds with conventional social organizations (HIRSCHI, 1969). It logically implies that these sources of control have a positive association with measures of conventionally and conformity, and a negative association with measures of deviant behavior (ROHRBAUGH; JESSOR, 1975).

According to social control theories of adolescent behavior, religious functions as encouragement to adolescents to avoid actions that they might otherwise have carried out (REGNERUS, 2007; ROSTOSKY et al., 2004; SMITH, 2003; DeLAMATER, 1981; ROHRBAUGH; JESSOR, 1975). This influence of religion has frequently been seen as an inhibiting force, which may contribute to postpone, reduce or even repress certain behaviors, such as adolescent sexual activity.

\section{The association between Pentecostalism and sexual initiation in Brazil}

The last few decades have witnessed a rapid and widespread transformation of Brazil's religious landscape (BURDICK, 1993; DECOL, 1999; PIERUCCI; PRANDI, 2000; CHESNUT, 2003; ALVES; BARROS; CAVENAGHI, 2012). In this process, the expansion of Protestantism has attracted special attention; the proportion of Protestants increased from less than three percent in 1940 to 22 percent in 2010. This growth was concomitant with the waning of the Roman Catholic domination of the Brazilian religion market. According to data from the Brazilian censuses, the percentage of Catholics in Brazil dropped from 95\% in 1940 to 65\% in 2010 . 
Catholicism in Brazil has long been blamed for permitting flexibility and variety regarding its religious practices. It became an "easy religion" in Brazil, a "church very often regarded as a social necessity - a comfortable presence rather than a compelling force" (BRUNEAU, 1982, p. 21). As noted by Pierucci and Prandi (2000), "traditional Catholics" still comprise the majority of the Catholic Church in Brazil today. This term "traditional Catholics", refers to those who attend church sporadically and are not involved in renewal movements, such as Basic Christian Communities or the Catholic Charismatic Renewal.

This rise of Protestantism in Brazil is largely due to the growth of Pentecostal denominations. In his book about the Pentecostal boom in Brazil, Chesnut (1997) emphasized that Pentecostal Protestantism has enjoyed overwhelming success based on the idea of a behavior transformation for this group. Believers, for instance, cannot claim to be fully converted until they have completely abandoned secular pleasures. Several Pentecostal churches, for instance, strongly disapprove of the consumption of alcohol, use of illicit drugs, smoking, and premarital and extra-marital sexual relations (MARIANO, 2005). Burdick (1993), for example, argued that courting is closely regulated in Pentecostal churches, such as the Assemblies of God, where premarital sex is considered a serious sin. According to the author, "those who surrender to temptation [premarital sex] may be severely disciplined, even excluded from communion for a time, and may suffer the withdrawal of the Holy Spirit" (BURDICK, 1993, p. 131).

Sacred teachings and values offered by Pentecostal churches in Brazil, therefore, may directly affect the sexual behavior of their adolescent followers. Furthermore, these churches may work through key pathways to indirectly influence adolescents' attitudes and behaviors. The work by Smith (2003) formulates an integrated account of religion's influence on the lives of American adolescents, suggesting key factors or pathways through which religion may act. These are aggregated around dimensions, such as learned competences (which consist of community and leadership skills, coping skills, and cultural capital), and social and organizational ties (that include social capital, network closure, and extra-community links).

Some of these religious pathways may be more closely associated with adolescent sexual behavior. The development of leadership skills, for example, represents a useful capability that can positively affect adolescents' opportunities at school and in the labor market (REGNERUS, 2000; MULLER; ELLISON, 2001; GLANVILLE; SIKKINK; HERNÁNDEZ, 2008), increasing their self-confidence and life chances. Higher expectations and better opportunities may represent motivation (especially for adolescent girls) to avoid certain behaviors, including premarital sexual relations, which are sometimes associated with early dropout from school and unplanned pregnancies.

Another potential source of religious influence on adolescent sexual behavior may occur through social ties. Smith (2003) argues that religious institutions emphasize personal interactions with fellow believers of all ages and life stages, providing youth with contact with adult members and encouraging social relations within a context governed by norms of trust, care, and mutual obligation. These networks may be a source of helpful information, 
resources, and opportunities that create conditions of increased support for and supervision of youth (MULLER; ELLISON, 2001; KRAUSE et al., 2001; SMITH, 2003).

Although there is almost no empirical evidence as to how these mechanisms work in Brazil, Pentecostal churches in the country may be offering an environment for the emergence of some of the pathways suggested above. Pentecostal churches in Brazil, for instance, are usually made up of small groups of followers that meet weekly to read the bible and pray. In these groups (very often called cells), ordinary people may have opportunity to develop leadership skills that can increase capacities and confidence (MARIZ, 1994). Pentecostals in Brazil are also recognized for their promotion of self-help networks that offer not only psychological and spiritual support, but also financial (BURDICK, 1993; CHESNUT, 2003; WOOD; WILLIAMS; CHIJIWA, 2007). These connections, based on a religious environment, can also expand youth's aspirations, encouraging their development and maturity, and restrict their free time, which may indirectly affect their sexual and reproductive behavior as well. Moreover, these networks of relational ties may affect adolescents' attitudes by enabling parents and older religiously involved people to supervise and pay closer attention to them (SMITH, 2003).

\section{Data}

This article makes use of data from the PNDS-2006 National Survey on the Demography and Health of Children and Women) (Pesquisa Nacional de Demografia e Saúde da Criança e da Mulher), a nationally representative survey of women aged 15-49 years, which contains detailed information on sexual and reproductive behavior, as well as questions on religious affiliation and attendance at religious services. In the analyses that follow, we investigate whether religious denominations and attendance are associated with age at first sexual intercourse among female adolescents (aged 15-19) in Brazil, when adjusting for key variables. Since the histories of these women are incomplete, the experiences of young adults aged 20-24 (women who have recently completed their teen years) are also considered. Moreover, because of the intermingling effects of marriage and sexual activity, this analysis estimates the risk of the first sexual intercourse being premarital-specifically, first intercourse occurring either before the first union, whether formal or informal, or before the age of 20, for unmarried women (GUPTA, 2000). The PNDS-2006 measures age at first sexual intercourse and age at first union in numbers of full years. As pointed out by Gupta (2000), this way of measuring can easily lead to underestimated rates of premarital activity because some sexual relations occurring within the few months preceding marriage are considered marital events.

The PNDS-2006 classifies religious affiliation into six groups: (1) Roman Catholicism, (2) Traditional Protestantism, (3) Pentecostalism, (4) Spiritism, (5) Afro-Brazilian religions, and (6) others. Taken together, approximately $3 \%$ of the adolescents and young women reported belonging to the last three religious affiliation groups in 2006. Because these denominations may show a great variety of beliefs and practices, and represent a very small portion of the 
sample, they were excluded from our analysis. Finally, the religious affiliation variable also contains a no-religion category. Our final sample included a total of 4,617 young women between the ages of 15 and 24 .

The PNDS collects information on attendance at religious services, which allows using a measure of religiosity as well. The PNDS-2006 classifies religious service attendance into five groups: (1) More than weekly; (2) Weekly; (3) Once to three times a month; (4) Less than monthly; (5) Does not attend.

One serious limitation of our data is that religious information generally refers to characteristics reported at the time of the survey (e.g., current religious denomination and attendance at religious services), whereas the variable being focused on (age at first intercourse) is retrospective in nature. Therefore, it is not possible to assure that at the time the adolescent had her first sexual intercourse she was Pentecostal or Catholic, or was attending church once per week or per month.

Another limitation refers to the cross-sectional nature of the PNDS data, which do not allow identification of the temporal order of events. It is impossible to discern the direction of causalities. That is, we will never know whether decisions on premarital sexual behavior may have caused decisions regarding religious involvement, orthe other way around.

Because the PNDS-2006 is based on a stratified two-stage cluster design, the sampling weights and units (used in clustering) must be specified (CAVENAGHI, 2009a). In Version 10 of the STATA software, this is possible by using the "svyset" command, which produces estimates of standard errors and statistical tests that are corrected for the complex design of the survey. All descriptive and statistical analyses shown here are corrected by this command and conducted using STATA, Version 10.

\section{Analytical strategy}

We employ Cox proportional hazard models, which comprise a semiparametric method that do not require to choose some probabilistic distribution to represent survival times (ALLISON, 2005). We use Cox models because they allow for analysis of the data using a temporal dimension when controlling for key covariates. In other words, the Cox model relates the time of an event (such as age at first sexual intercourse) to a number of explanatory variables that could confound the association examined here, that is, the association between religion and age at first sexual intercourse.

We present our findings through a set of three adjusted statistical models. In the first two models we test whether the hazard ratios ${ }^{1}$ of a young woman in Brazil to have her first adolescent and premarital sexual intercourse is associated with (1) religious affiliation and with (2) attendance at religious services.

\footnotetext{
${ }^{1}$ The hazard ratio is the probability of an event occurring in time $t+1$, given survival to time $t$. Results expressed in terms of hazard ratio are easy to interpret: a ratio higher (or lower) than one implies that, all else being equal, a young women in a given category would be more (or less) likely to experience pre-marital first sex before age 20 than a counterpart in the base category.
} 
We then present our third Cox model by showing the association between the hazard ratios of having premarital adolescent sexual intercourse, and having a religious denomination and attending religious services, simultaneously. In an attempt to avoid multicollinearity due the high correlation between religious denomination and religious service attendance (as suggested in Table 1), we created six mutually exclusive dichotomous variables representing combinations of the three religious affiliations, with two different frequencies of attendance at religious service. In order to facilitate their interpretation in the results, we re-categorized the religious services attendance variable into two groups, namely, (1) young women who attended religious services less than weekly, and (2) those who attended weekly or more often. The new six mutually exclusive dichotomous variables include (1) Catholics who go to church weekly or more often, (2) Catholics who go to church less often than weekly (the reference group), (3) Traditional Protestants who attend religious services weekly or more often, (4) Traditional Protestants who attend services less often than weekly, (5) Pentecostals who go to church weekly or more often, and (6) Pentecostals who go less often than weekly.

Because adolescent sexual behavior and religious affiliation and religious service attendance differ significantly in a number of socioeconomic, demographic, and community characteristics in Brazil, it is important to adjust our results for these factors as effectively as possible. Other independent variables used in our analysis included a dichotomous variable based on the information for two age groups: 15-19 years (the reference group) and 20-24; three groups of years of schooling: 0-4 years (reference), 5-8 years of schooling, and nine years or more; a dichotomous variable based on the information for currently living in urban areas (rural is the reference) and for childhood residence (lived in a small city when she was twelve is the reference); and five categories for region of residence (Northeast is the reference).

We also attempted to assess socioeconomic status (SES) with a household variable created on the basis of a method suggested by the Associação Brasileira de Empresa de Pesquisas (ABEP, 2008). This method employs information on the education of the head of the household in addition to nine amenities in the household, including the number of television sets, DVDs, radios, bathrooms, automobiles, washing machines, refrigerators, freezers, and persons providing domestic help. In fact, this indicator is a proxy for a wealth index based on a household's propensity to consume. The PNDS-2006 household dataset provides all the variables necessary to calculate this aggregate indicator (CAVENAGHI, 2009b). The range of this measure is from 0 to 7 , the 7 being the highest level of the household's propensity to consume - and is treated as continuous in our analyses.

\section{Results}

Table 1 shows the percentage of young women (ages 15-24) per religious affiliation and attendance at religious service in Brazil in 2006. While 63\% of them reported being affiliated 
with the Catholic Church, 14\% and 11\% identified themselves as traditional Protestants, and Pentecostals, respectively. Information on religious attendance shows a heterogeneous pattern. While $39 \%$ of young women report attending religious services at least weekly, $44 \%$ attend less than monthly or never go. Table 1 also indicates that young women in Brazil who belong to traditional Protestant and Pentecostal churches attend religious services far more often than those of the Catholic Church. On this point, there is a clear divide in religiosity separating Protestants from Catholics.

TABLE 1

Weighted percentage of religious affiliation by religious attendance among young women (15-24) Brazil - 2006

\begin{tabular}{|c|c|c|c|c|c|c|c|c|c|c|c|c|}
\hline \multirow{3}{*}{$\begin{array}{l}\text { Religious affiliation } \\
\text { (1) }\end{array}$} & \multicolumn{12}{|c|}{ Religious attendance } \\
\hline & \multicolumn{2}{|c|}{$\begin{array}{c}\text { Weekly or } \\
\text { more }\end{array}$} & \multicolumn{2}{|c|}{ Weekly } & \multicolumn{2}{|c|}{$\begin{array}{l}\text { Less than } \\
\text { weekly }\end{array}$} & \multicolumn{2}{|c|}{$\begin{array}{c}\text { Less than } \\
\text { monthly }\end{array}$} & \multicolumn{2}{|c|}{ Never } & \multicolumn{2}{|c|}{ Total } \\
\hline & $\mathrm{N}$ & $\%$ & $\mathrm{~N}$ & $\%$ & $\mathrm{~N}$ & $\%$ & $\mathrm{~N}$ & $\%$ & $\mathrm{~N}$ & $\%$ & $\mathrm{~N}$ & $\%$ \\
\hline Catholic & 257 & 8 & 802 & 23 & 652 & 21 & 894 & 30 & 481 & 18 & 3,097 & 63 \\
\hline Traditional Protestant & 214 & 44 & 164 & 28 & 83 & 11 & 81 & 14 & 18 & 3 & 560 & 14 \\
\hline Pentecostal & 256 & 55 & 106 & 23 & 51 & 13 & 29 & 8 & 13 & 1 & 456 & 11 \\
\hline No religion & 5 & 2 & 25 & 4 & 29 & 4 & 85 & 20 & 372 & 70 & 504 & 12 \\
\hline Total & 732 & 18 & 1,097 & 21 & 815 & 17 & 1,089 & 24 & 884 & 20 & 4,617 & 100 \\
\hline
\end{tabular}

Source: Ministério da Saúde. Pesquisa Nacional de Demografia e Saúde da Criança e da Mulher 2006. (1) p-value $<0.001$.

Table 2 shows the percentage distribution of young women (ages 15-24) in 2006 by certain demographic and socioeconomic characteristics. The proportion of young women who had at least nine years of education ( $56 \%$ ) is higher than those who had less than nine years. While $81 \%$ of the girls lived in urban areas in $2006,43 \%$ of them reported that they had lived in large cities during childhood. Moreover, Table 2 shows a high heterogeneous distribution of young women living in the five Brazilian geographical regions. As expected, the majority lived in the Southeast and Northeast in 2006. Finally, Table 2 shows the mean household SES (2.2).

Graph 1 shows the cumulative survival distribution of the transition to premarital sexual initiation per age at first sexual intercourse for the three main religions in Brazil and for those young women who identified themselves as having no religion. The graph shows differences between Catholic and Protestant (including Pentecostal) young women in the probability that they will remain virgins during their adolescence at a given age. Catholics tend to initiate their premarital sexual life earlier than their non-Catholic counterparts. But they report having had their first sexual experience later than those who have no religion, which is the group who began their sexual life at the earliest age. Graph 1 presents the cumulative survival functions by the five levels of attendance at religious services. At all ages, those who attended religious services at least weekly showed lower probability of reporting having had premarital sexual intercourse than those who attended religious services less frequently. 
TABLE 2

Weighted percentage of young women (15-24) by selected characteristics

Brazil - 2006

\begin{tabular}{|c|c|c|}
\hline Variables & $\mathrm{N}$ & $\%$ \\
\hline \multicolumn{3}{|l|}{ Age } \\
\hline $15-19$ & 2,399 & 51 \\
\hline $20-24$ & 2,218 & 49 \\
\hline \multicolumn{3}{|l|}{ Years of education } \\
\hline 0 to 4 & 432 & 9 \\
\hline 5 to 9 & 1,683 & 35 \\
\hline 9 or over & 2,502 & 56 \\
\hline \multicolumn{3}{|l|}{ Residence } \\
\hline Rural & 1,370 & 19 \\
\hline Urban & 3,247 & 81 \\
\hline \multicolumn{3}{|l|}{ Residence at childhood } \\
\hline Small City & 2,930 & 57 \\
\hline Large City/Metropolis & 1,687 & 43 \\
\hline \multicolumn{3}{|l|}{ Regions } \\
\hline Northeast & 1,018 & 29 \\
\hline North & 884 & 9 \\
\hline Southeast & 924 & 42 \\
\hline South & 841 & 13 \\
\hline Central-West & 950 & 7 \\
\hline \multicolumn{3}{|l|}{ Household socioeconomic index } \\
\hline Mean & 4,617 & 2.2 \\
\hline$(\mathrm{N})$ & 4,617 & 4,617 \\
\hline
\end{tabular}

Source: Ministério da Saúde. Pesquisa Nacional de Demografia e Saúde da Criança e da Mulher 2006.

GRAPH 1

Survival distribution of premarital first sexual initiation, by religious affiliation and attendance at religious services

Brazil - 2006
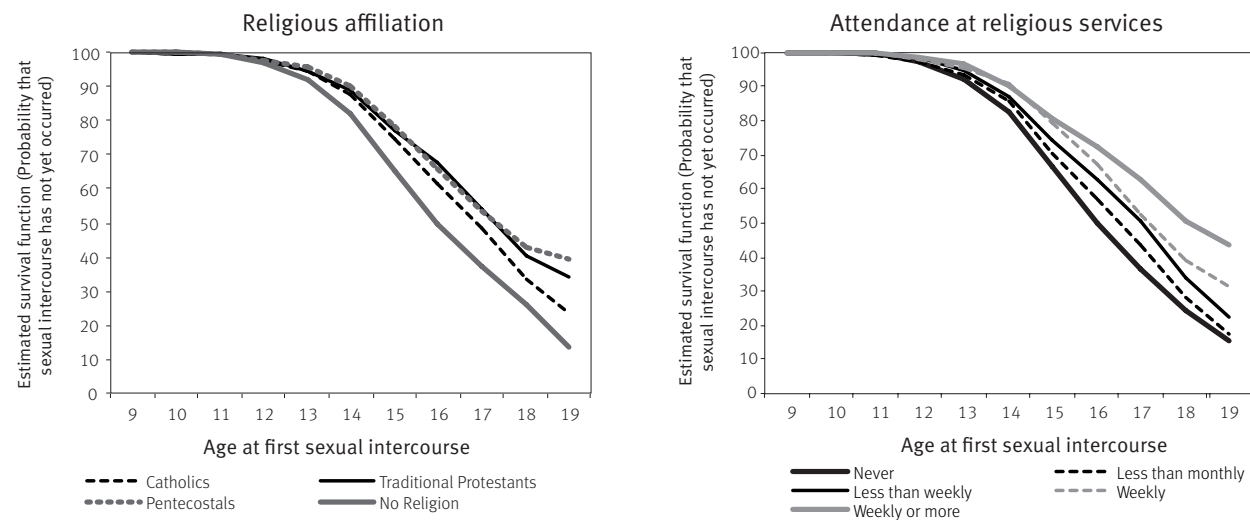

Source: Ministério da Saúde. Pesquisa Nacional de Demografia e Saúde da Criança e da Mulher 2006.

As can be seen in Table 3, Model 1 shows that, in Brazil, in contrast to belonging to the Catholics belonging to a Pentecostal congregation is associated with delaying first premarital sexual intercourse during adolescence, even demographic and socioeconomic factors are controlled. Table 3 also shows that attendance at religious services is inversely associated 
with the hazard ratio of initiating premarital sexual activity (Model 2). All else being equal, the more often young women attend religious services, the lower is their risk of having had premarital sexual intercourse during adolescence.

TABLE 3

Hazard ratios from the Cox proportional models showing the risk of young women having premarital first intercourse during adolescence

Brazil - 2006

\begin{tabular}{|c|c|c|c|}
\hline Variables & Model 1 & Model 2 & Model 3 \\
\hline \multicolumn{4}{|l|}{ Age } \\
\hline $15-19$ & 1.00 & 1.00 & 1.00 \\
\hline $20-24$ & $1.18^{\star \star}$ & $1.14^{\star}$ & $1.15^{\star}$ \\
\hline \multicolumn{4}{|l|}{ Religious affiliation } \\
\hline Catholic & 1.00 & & \\
\hline Traditional Protestant & $0.78^{\star}$ & & \\
\hline Pentecostal & $0.79 * \star$ & & \\
\hline No Religion & 1.22 & & \\
\hline
\end{tabular}

\section{Religious attendance}

Never

1.00

Less than monthly

Less than weekly

0.84

Weekly

$0.72^{\star *}$

Weekly or more

\section{Religious affiliation by attendance}

Catholics with low attendance

Catholics with high attendance

Pentecostals with low attendance

Pentecostals with high attendance

Traditional Protestants with low attendance

$0.66^{\star \star \star}$

$0.55^{\star \star \star}$

Traditional Protestants with high attendance

No Religion

\section{Years of education}

0 to 4

5 to 8

9 or over

\section{Residence}

Rural

Urban

Residence at childhood

Small City

Large City/Metropolis

Regions

Northeast

North

Southeast

South

Central-West

\section{Household socioeconomic index}

Mean

2 log-likelihood

$(\mathrm{N})$

attendance

\begin{tabular}{|c|c|c|}
\hline & & $\begin{array}{l}1.00 \\
0.83^{\star \star} \\
1.76^{\star \star} \\
0.53^{\star \star \star} \\
0.73 \\
0.74^{\star} \\
1.14\end{array}$ \\
\hline $\begin{array}{l}1.00 \\
0.83 \\
0.59^{\star \star \star}\end{array}$ & $\begin{array}{l}1.00 \\
0.85 \\
0.61^{\star \star \star}\end{array}$ & $\begin{array}{l}1.00 \\
0.83 \\
0.59^{\star \star \star}\end{array}$ \\
\hline $\begin{array}{l}1.00 \\
1.32^{\star \star}\end{array}$ & $\begin{array}{l}1.00 \\
1.33^{\star \star}\end{array}$ & $\begin{array}{l}1.00 \\
1.36^{\star \star}\end{array}$ \\
\hline $\begin{array}{l}1.00 \\
1.24^{\star \star}\end{array}$ & $\begin{array}{l}1.00 \\
1.22^{\star \star}\end{array}$ & $\begin{array}{l}1.00 \\
1.25^{\star \star}\end{array}$ \\
\hline $\begin{array}{l}1.00 \\
1.81^{\star \star} \\
1.56^{\star \star} \\
1.77^{\star \star} \\
1.50^{\star \star} \\
\end{array}$ & $\begin{array}{l}1.00 \\
1.89^{\star \star} \\
1.59^{\star \star} \\
1.77^{\star \star} \\
1.52^{\star \star}\end{array}$ & $\begin{array}{l}1.00 \\
1.87^{\star \star} \\
1.58^{\star \star} \\
1.78^{\star \star} \\
1.50^{\star \star}\end{array}$ \\
\hline $\begin{array}{l}0.93^{\star \star} \\
36.601\end{array}$ & $\begin{array}{l}0.93^{\star *} \\
36.531\end{array}$ & $\begin{array}{l}0.93^{\star \star} \\
36.534\end{array}$ \\
\hline
\end{tabular}

Source: Ministério da Saúde. Pesquisa Nacional de Demografia e Saúde da Criança e da Mulher 2006.

${ }^{*} p$-value $<0.1{ }^{* *} p$-value $<0.05{ }^{* * *}$ p-value $<0.01$

In addition, our subsequent model (Model 3) suggests at least three main findings concerning the association between premarital sexual initiation during adolescence and the variables representing combinations between religious affiliation and attendance at religious 
services. First, Catholic young women with high attendance at religious services were at a lower statistical significant risk of engaging in adolescent premarital first sex than Catholics who attended less frequently ( $H R=0.83 ; p<0.01)$. Second, Pentecostals with high attendance were at a statistically significant lower risk of engaging in premarital sexual intercourse during adolescence $(H R=0.53 ;$ p 0.01$)$ than Catholics with low attendance. Even when compared to Catholics with high attendance, Pentecostals who go to church at least weekly are less likely to engage in premarital adolescent sexual intercourse ( $\mathrm{HR}=0.62 ; \mathrm{p}<0.01$; results not shown). Lastly, Model 3 indicates that in 2006 Pentecostals with low church attendance presented a substantial higher risk of having premarital first sex $(H R=1.76$; $p<0.01)$ than Catholics who attended religious services on the same basis.

Not surprisingly, education is found to have a statistically significant association with premarital adolescent sexual initiation in Brazil. Young women with at least nine years of schooling were at a significantly lower risk of engaging in premarital adolescent sexual initiation than those with less than five years of schooling, all else being equal. Urban residence was associated with a higher risk of early premarital sexual intercourse during adolescence than rural residence. Similar results can be noted for childhood place of residence. Young women who spent their earliest years in an urban environment (who lived in a large city or capital city) were at a higher risk of engaging in premarital sexual activity during adolescence than those whose early environment had been in rural areas or small towns. Moreover, the hazard ratios by region of residence show that girls who lived either in the North, the South, the Southeast, or the Center-west of Brazil in 2006 were at higher risk of premarital sexual initiation than those living in the Northeast. Finally, residence in a household of higher SES is associated with a lower risk of premarital adolescent sexual initiation.

\section{Discussion}

Previous studies have suggested several determinants associated with adolescent sexual activity in Brazil (see, for example, BORGES; LATORRE; SCHOR, 2007; CESARE; RODRIGUEZVIGNOLI, 2006; BOSON, 2005; BRANDÃO, 2004; AQUINO et al., 2003; GUPTA, 2000; GUPTA; LEITE, 1999). Surprisingly, little is known about the implications of religious involvement for adolescent sexual and reproductive behavior in Brazil. When religion is considered in studies on this topic, it is usually used simply as a control variable (e.g., Catholics versus non-Catholics), or measured so broadly that the significance of the results is quite limited. Moreover, the majority of these studies take into account only one dimension of religious involvement in their analyses, namely, religious affiliation.

Most studies about Pentecostalism emphasize its pietism and conservative values. Among other points Pentecostal practical theology places a ban on premarital sexual relations, which may directly influence sexual adolescents' behavior in Brazil (BURDICK, 1993; CHESNUT, 2003; MCKINNON; POTTER; GARRARD-BURNETT, 2008, OGLAND et al., 2010). Different authors emphasize that this restricting regimen is sustained by social sanctions in 
closed communities (MARIZ, 1994). Moreover, Pentecostal churches in Brazil have offered different resources to create spaces for adolescents and young followers in general to actively participate in a religious environment, increasing their exposure to the types of indirect influence of religion outlined by Smith (2003).

One of the main studies that have recently contributed to a better understanding of the association between religion and adolescent reproductive behavior in Brazil was conducted by McKinnon, Potter, and Garrard-Burnett (2008). Using the 2000 Brazilian National Census, this article explored the relationships between Protestantism, fertility and family formation among adolescents between the ages of 15 and 17 living in the metropolitan region of Rio de Janeiro. According to the main results, the odds of ever having had a live birth for adolescent women aged 15 to 17 belonging to Baptist, other Mainline Protestant, Assembly of God, or other Pentecostal churches is about one third lower than those for Catholics. It also notes that adolescents who belong to the Assembly of God, other Pentecostal Protestant, or other mainline Protestant churches are much more likely to be married than Catholics. More recently, Verona and Dias Junior (2012) found that adolescent females who showed higher attendance at religious services and belonged to Pentecostal churches at the time of the interview have lower risk of showing adolescent premarital fertility in 1996 and 2006, respectively.

Our findings corroborate those of McKinnon, Potter, and Garrard-Burnett (2008) and Verona and Dias Junior (2012), and reveal that young women who belonged to Pentecostal churches at the time of the interview were at a lower risk of engaging in adolescent premarital first sexual intercourse than those who belonged to the Catholic Church. In addition, the risk of premarital sexual initiation during adolescence was also lower among girls who currently attended religious services regularly as compared to those who never participated, even after demographic and socioeconomic variables, also measured at the time of the interview, were controlled. These findings would seem to corroborate the standards and values taught in Protestant churches, especially in Pentecostal denominations. Moreover, Pentecostal churches may be more effective at convincing adolescent women to avoid or postpone premarital sexual intercourse because they encourage girls to attend religious services regularly.

This result, however, must be interpreted with caution. It is important to highlight that other factors may be at work in the apparent association between religion and premarital adolescent sexual behavior. It is possible, for instance, that Pentecostals - for whom premarital sex is a more serious violation of norms than for most other Christian groups - and girls who regularly attend their churches suffer from greater social desirability bias ${ }^{2}$ in matters of both sex and religiosity. If so, the hazard ratios for the religious affiliation and attendance variables reported here may be overestimated. However, should this bias exist, it would probably not account for the entire difference observed between Pentecostal and Catholic girls (or between those who attend church regularly and those who rarely attend).

\footnotetext{
${ }^{2}$ This bias is the inclination to present oneself in a manner that will be viewed favorably by others. It can affect how respondents answer research questions, therefore, confusing the results (PRESSER; STINSON, 1998).
} 
Another important finding was the difference between Pentecostal youth who attend church on a weekly basis and those who rarely attend. The former group showed the lowest risk of experiencing premarital sexual intercourse during adolescence, while the latter showed the highest risk. These results indicate the importance of considering attendance at religious groups and services when studying the association between religion and sexual initiation in Brazil. This is true because adolescents with greater religious commitment, even in the same religious congregation, may be more apt than others to reproduce religious values and teachings in their actions. Therefore, assuming that attendance at religious services is a measure of religious commitment, this may help differentiate among adolescents that belong to the same religion.

Nevertheless, our findings suggesting that Pentecostals with low attendance show a substantially higher risk of having premarital first sex are unexpected. In fact, the research that has been conducted has pointed to Pentecostal Protestant churches as those that may be most effective at helping adolescents to avoid certain behaviors, including premarital childbearing (MCKINNON; POTTER; GARRARD-BURNETT, 2008; OGLAND et al., 2010). One explanation for such a finding would be given by the hypothesis of reverse causality. That is to say, some of these girls may not be attending church any longer because they were ashamed at having had premarital sexual intercourse, creating an illusory association between virginity and those who do not self-select out of religion (REGNERUS; SMITH, 2005). Previous research, for instance, has provided evidence to support the idea that young Pentecostal women who transgress the norm of virginity may be inclined or motivated to leave their congregation (temporarily or permanently) (MARIZ, 1994). Therefore, because this research uses crosssectional data, the direction of the causality may be reversed, that is, decisions related to premarital sexual behavior may be causing decisions on religious involvement - such as attendance at religious services - and not the contrary.

In addition, PNDS-2006 does not allow for differentiation between voluntary and forced first sexual intercourse. This is another limitation of our data, since such a lack of distinction can hide important information about female control over first sexual intercourse (MOORE, 2006). Unwanted first sexual intercourse may be related to demographic outcomes such as early sexual intercourse, use of contraceptives and unplanned pregnancies.

Finally, this study revealed a substantial difference in the risk of having premarital sexual initiation during adolescence among Catholics who frequently attend religious services and those who attend less often. Therefore, attendance at religious services may be also important in influencing adolescent sexual behavior among Catholics. Unfortunately, (using the existing data), there is no way to know whether Catholic girls who attend religious services on a regular basis are also influenced by the Catholic charismatic movement. But one can assume that a large number of them do participate in this renewal movement, and this may help explain their lower risk of first premarital sexual when compared to Catholics with low attendance (probably traditional Catholics). This finding must be investigated in greater detail in future research. 


\section{Conclusion}

Our main results suggest an association between premarital sexual initiation and Pentecostalism in Brazil and also suggest that this association may take place through frequent attendance at religious services. These findings are intriguing, to say the least, especially because Pentecostalism has emerged in and been concentrated among socioeconomically disadvantaged populations, including the least-educated women, those with lower income, and residents of urban areas.

We conclude by suggesting that religion may be taking the place of family and school in communicating about adolescent sexual and reproductive behavior in Brazil. Although many scholars agree on the need to promote discussion of issues related to sexuality among this audience, in practice, parents and educators still have difficulties in addressing the issue. It can be seen that some religions or churches have established rules of conduct and, at the same time, offer space for social interaction and learning techniques and skills. It can therefore be expected that they are becoming one of the few channels of information on the subject among young people in the country. This hypothesis should be carefully investigated.

\section{References}

ABEP - Associação Brasileira de Empresa de Pesquisa. Critério Brasil mede o poder aquisitivo do consumidor. Unpublished report, 2008.

ALLISON, P. D. Survival analysis using SAS - A practical guide. Cary, NC: SAS, 2005.

ALVES, J. E. D.; BARROS, L. F. B.; CAVENAGHI, A dinâmica das filiações religiosas no Brasil entre 2000 e 2010: diversificação e processo de mudança de hegemonia. Rever, v. 2, n. 12, p. 145-174, 2012.

AQUINO, E. M. L. et al. Adolescence and reproduction in Brazil: the heterogeneity of social profiles. Cadernos de Saúde Pública, v. 19 (sup.2), p. s337-s388, 2003.

BANKOLE, A.; MALARCHER, S. Removing barriers to adolescents' access to contraceptive information and services. Studies in Family Planning, v. 41, n. 2, p. 117-124, 2010.

BEMFAM - Sociedade Civil Bem-Estar Familiar no Brasil; INSTITUTE FOR RESOURCE DEVELOPMENT. Pesquisa Nacional sobre Saúde Materno-Infantil e Planejamento Familiar - PNSMIPF - Brasil, 1986. Rio de Janeiro: Bemfam, 1987.

BONGAARTS, J.; COHEN, B. Introduction and overview. Studies in Family Planning, v. 29, n. 2, p. 99-105, 1998.

BORGES, A. L. V.; LATORRE, M. R. D.; SCHOR, N. Factors associated with sexual debut among adolescents enrolled in a family health unit in East Side São Paulo, Brazil. Cadernos de Saúde Pública, v. 23, n. 7, p. 1583-1594, 2007.

BOZON, M. Novas normas de entrada na sexualidade no Brasil e na América Latina. In: HEILBORN, M.

L. et al. Sexualidade, família e ethos religioso. Rio de Janeiro: Garamond, 2005.

BRASIL. Ministério da Saúde. Pesquisa Nacional de Demografia e Saúde da Criança e da Mulher 2006. Brasília: MS/ São Paulo: Cebrap, 2008.

BRANDÃO, E. R. Iniciação sexual e afetiva: exercício da autonomia juvenil. In: HEILBORN, M. L. (Org.). Família e sexualidade. Rio de Janeiro: Editora FGV, 2004. 
BRUNEAU, T. C. The church in Brazil - the politics of religion. Austin: University of Texas Press, 1982. BURDICK, J. Looking for god in Brazil. Berkeley: University of California Press, 1993.

CAVENAGHI, S. M. Aspectos metodológicos e comparabilidade com pesquisas anteriores. In: BRASIL. Ministério da Saúde. Pesquisa Nacional de Demografia e Saúde da Criança e da Mulher PNDS 2006: dimensões do processo reprodutivo e da saúde da criança. Brasília: Ministério da Saúde, Centro Brasileiro de Análise e Planejamento, 2009a, v. 1, p. 13-32 (Série G. Estatística e Informação em Saúde).

Perfil dos domicílios e das famílias. In: BRASIL. Ministério da Saúde e Cebrap (Orgs.). Pesquisa Nacional de Demografia e Saúde da Criança e da Mulher PNDS 2006: dimensões do processo reprodutivo e da saúde da criança. 1 ed. Brasília: Ministério da Saúde, 2009b, v. 1, p. 33-54.

CESARE, M.; RODRIGUEZ-VIGNOLI, J. Micro analysis of adolescent fertility determinants: the case of Brazil and Colombia. Papeles de Población, n. 48, p. 94-121, 2006.

CHESNUT, R. A. Born again in Brazil - the Pentecostal boom and the pathogens of poverty. New Brunswick, NJ: Rutgers University Press, 1997. Press, 2003

Competitive spirits - Latin America's new religious economy. New York: Oxford University

DECOL, R. D. Mudança religiosa no Brasil: uma visão demográfica. Revista Brasileira de Estudos de População, v. 16, n. 1/2, p. 121-137, 1999.

DeLAMATER, J. The social control of sexuality. Annual Review of Sociology, n. 7, p. 263-290, 1981

GLANVILLE, J.; SIKKINK, D.; HERNÁNDEZ, E. Religious involvement and educational outcomes: the role of social capital and extracurricular participation. The Sociological Quarterly, n. 49, p. 105-137, 2008.

GUPTA, N. Sexual initiation and contraceptive use among adolescent women in Northeast Brazil. Studies in Family Planning, v. 31, n. 3, p. 228-238, 2000.

GUPTA, N.; LEITE, I. C. Adolescent fertility behavior: trends and determinants in Northeastern Brazil. International Family Planning Perspectives, v. 25, n. 30, p. 125-130, 1999.

HEILBORN, M. A.; AQUINO, E. M.; KNAUTH, D. R. Youth, sexuality and reproduction. Cadernos de Saúde Pública, n. 22, p. 1362-1363, 2006.

HINDIN, M. J.; FATUSI, A. O. Adolescent sexual and reproductive health in developing countries: an overview of trends and interventions. International Perspectives on Sexual and Reproductive Health, v. 35, n. 2, p. 58-62, 2009.

HIRSCHI, T. Causes of delinquency. Berkeley: University of California Press, 1969.

KRAUSE, N. et al. Church-based social support and religious coping. Journal for the Scientific Study of Religion, v. 40, n. 4, p. 637-656, 2001.

MARIANO, R. Neopentecostais: sociologia do novo pentecostalismo no Brasil. São Paulo: Loyola, 2005.

MARIZ, C. Coping with poverty: Pentecostal and Christian base communities in Brazil. Philadelphia, PA: Temple University Press, 1994.

McKINNON, S.; POTTER, J.; GARRARD-BURNETT, V. Adolescent fertility and religion in Rio de Janeiro, Brazil in the year 2000: the role of Protestantism. Population Studies, v. 62, n. 3, p. 289-303, 2008.

MOORE, A. M. Gender role beliefs at sexual debut: qualitative evidence from two Brazilian cities. International Family Planning Perspectives, v. 32, n. 1, p. 45-51, 2006.

MULLER, C.; ELLISON, C. Religious involvement, social capital, and adolescents' academic progress: evidence from the nation education longitudinal study of 1988. Sociological Focus, v. 34, n. 2 , p. 155-183, 2001. 
OGLAND, C. P.; BARTKOWSKI, J. P.; SUNIL, T. S.; XIAOHE, X. Religious influences on teenage childbearing among Brazilian female adolescents: a research note. Journal for the Scientific Study of Religion, v. 49, n. 4, p. 754-760, 2010.

PIERUCCI, A. F. O.; PRANDI, R. Religious diversity in Brazil: numbers and perspectives in a sociological evaluation. International Sociology, n. 15, p. 629-639, 2000.

PRESSER, S.; STINSON, L. Data collection mode and social desirability bias in self-reported religious attendance. American Sociological Review, v. 63, n. 1, p. 137-145, 1998.

REGNERUS, M. D. Forbidden fruit - Sex and religion in the lives of American teenagers. New York: Oxford University Press, 2007.

. Shaping schooling success: religious socialization and educational outcomes in metropolitan public schools. Journal for the Scientific Study of Religion, v. 39, n. 3, p. 363- 370, 2000.

REGNERUS, M. D.; SMITH, C. Selection effects in studies of religion influence. Review of Religious Research, v. 47, n. 1, p. 23-50, 2005.

ROHRBAUGH, J.; JESSOR, R. Religiosity in youth: a personal control against deviant behavior. Journal of Personality, n. 43, p. 136-155, 1975.

ROSTOSKY, S. S.; WILCOX, B. L.; WRIGHT, M. L.; RANDALL, B. A. The impact of religiosity on adolescent sexual behavior: a review of the evidence. Journal of Adolescent Research, v. 19, n. 6, p. 677-697, 2004.

SMITH, C. Theorizing religious effects among American adolescents. Journal for the Scientific Study of Religion, v. 42, n. 1, p. 17-30, 2003.

VERONA, A. P. A.; DIAS JUNIOR, C. S. Religião e fecundidade entre adolescentes no Brasil. Rev. Panam. Salud Publica, v. 31, n. 1, p. 25-31, 2012.

VERONA, A. P. A. Explanations for religious influence on adolescent sexual behavior in Brazil: direct and indirect effects. Revista Brasileira de Estudos de População, v. 28, n. 1, p. 187-201, 2011.

WOOD, C.; WILLIAMS, P.; CHIJIWA, K. Protestantism and child mortality in Northeast Brazil, 2000. Journal for the Scientific Study of Religion, v. 46, n. 3, p. 405-416, 2007.

\section{Authors}

Ana Paula A. Verona has PhD in Demography from the University of Texas at Austin. Is currently professor at the Department of Demography/ Center for Regional Development and Planning (Cedeplar), Universidade Federal de Minas Gerais - UFMG.

Mark Regnerus has PhD in Sociology from the University of North Carolina at Chapel Hill. Is currently associate professor of Sociology, Department of Sociology, University of Texas at Austin.

\section{Correspondence address}

Ana Paula A. Verona

Av. Antônio Carlos, 6627

Cedeplar-Face-UFMG

Belo Horizonte, MG - CEP 31270-901 


\section{Resumo}

Pentecostalismo e iniciação sexual pré-marital no Brasil

As igrejas pentecostais no Brasil são conhecidas por promoverem normas conservadoras e também sanções punitivas relacionadas ao comportamento sexual de seus jovens fiéis. Além disso, estas igrejas têm criado um espaço único para os seus seguidores participarem ativamente de um ambiente religioso. Usando dados da PNDS-2006 (Pesquisa Nacional de Demografia e Saúde da Criança e da Mulher), foram examinadas as associações entre religião, medida pela afiliação religiosa e frequência aos cultos e missas, e a iniciação sexual pré-marital de adolescentes no Brasil. Os principais resultados confirmam uma forte associação entre postergação da iniciação sexual e Pentecostalismo no Brasil e sugerem que esta associação também ocorre por meio da frequência aos cultos e massas. Estes resultados são intrigantes especialmente porque o Pentecostalismo abrange particularmente uma população com nível socioeconômico baixo, incluindo mulheres com baixa escolaridade e renda, e residentes de áreas urbanas. Conclui-se que religião possa estar tomando o lugar da família e da escola na comunicação sobre o comportamento sexual de adolescentes no Brasil. Esta hipótese deve ser cuidadosamente investigada, uma vez que ensinamentos religiosos podem estar a favor mas também contra o que a família e o Estado entendem como benéfico para os adolescentes e jovens no Brasil.

Palavras-chave: Religião. Religiosidade. Iniciação sexual pré-marital. Sexualidade de adolescentes.

\section{Resumen}

Pentecostalismo e iniciación sexual pre-nupcial en Brasil

Las iglesias pentecostales en Brasil son conocidas por promover normas conservacionistas y sanciones punitivas relacionadas con las prácticas sexuales de sus miembros más jóvenes. Además, crearon un espacio diferenciado para que sus seguidores participen activamente en el ambiente religioso. Utilizando datos del PNDS-2006 (Pesquisa Nacional de Demografia e Saúde da Criança e da Mulher de 2006), examinamos las asociaciones entre religión, medidas a través de la afiliación religiosa y la asistencia a los servicios religiosos, y la iniciación sexual pre-nupcial adolescente en Brasil. Nuestros principales resultados confirman una fuerte asociación entre la postergación de la iniciación sexual y el pentecostalismo en Brasil y sugiere que esta asociación también puede ocurrir debido a la alta tasa de participación en servicios religiosos. Estos hallazgos son intrigantes, especialmente porque el pentecostalismo emergió y se concentró entre las poblaciones más desposeídas a nivel socioeconómico, incluyendo ahí a mujeres con baja educación, bajos ingresos y residentes en áreas urbanas. Concluimos sugiriendo que la religión puede estar ocupando el papel de la familia y de la escuela en la comunicación del comportamiento sexual adolescente en Brasil. Esta hipótesis debe ser cuidadosamente investigada, una vez que las enseñanzas religiosas pueden apoyar, pero a veces también pueden estar en contra lo que la familia y el Estado entienden como benéficas para la juventud adolescente en Brasil.

Palabras-claves: Religión. Religiosidad. Iniciación sexual pre-nupcial. Sexualidad adolescente. 
